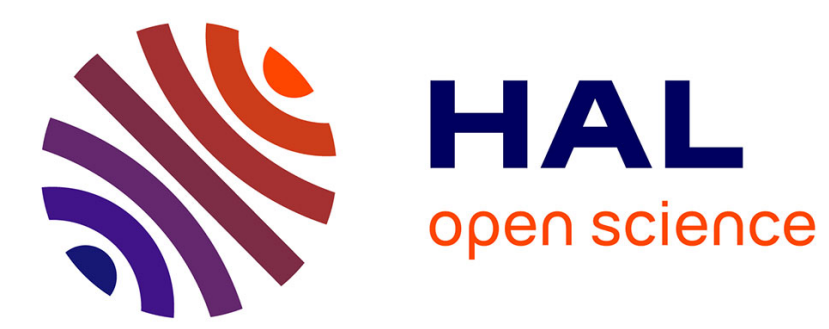

\title{
Do antibiotics have environmental side-effects? Impact of synthetic antibiotics on biogeochemical processes
}

Céline Roose-Amsaleg, Anniet M. Laverman

\section{To cite this version:}

Céline Roose-Amsaleg, Anniet M. Laverman. Do antibiotics have environmental side-effects? Impact of synthetic antibiotics on biogeochemical processes. Environmental Science and Pollution Research, 2016, 23 (5), pp.4000-4012. 10.1007/s11356-015-4943-3 . hal-01174217

HAL Id: hal-01174217

https://hal-univ-rennes1.archives-ouvertes.fr/hal-01174217

Submitted on 15 Sep 2015

HAL is a multi-disciplinary open access archive for the deposit and dissemination of scientific research documents, whether they are published or not. The documents may come from teaching and research institutions in France or abroad, or from public or private research centers.
L'archive ouverte pluridisciplinaire HAL, est destinée au dépôt et à la diffusion de documents scientifiques de niveau recherche, publiés ou non, émanant des établissements d'enseignement et de recherche français ou étrangers, des laboratoires publics ou privés. 


\section{Do antibiotics have environmental side-effects?}




\section{Abstract}

22 Antibiotic use in the early 1900 vastly improved human health but at the same time started an arms race of antibiotic resistance. The wide-spread use of antibiotics has resulted in ubiquitous trace concentrations of many antibiotics in most environments. Little is known about the impact of these antibiotics on microbial processes or "non-target" organisms. This mini-review summarizes our knowledge of the effect of synthetically produced antibiotics on microorganisms involved in biogeochemical cycling. We found only 31 articles that dealt with effects of antibiotics on such processes in soil, sediment, or freshwater. We compare the processes, antibiotics, concentration range, source, environment, and experimental approach of these studies.

Examining the effects of antibiotics on biogeochemical processes should involve environmentally relevant concentrations (instead of therapeutic), chronic exposure (versus acute) and monitoring of the administered antibiotics. Furthermore, the lack of standardized tests hinders generalizations regarding the effects of antibiotics on biogeochemical processes. We investigated the effects of antibiotics on biogeochemical $\mathrm{N}$ cycling, specifically nitrification, denitrification, and anammox. We found that environmentally relevant concentrations of fluoroquinolones and sulfonamides could partially inhibit denitrification. So far, the only documented effects of antibiotic inhibitions were at therapeutic doses on anammox activities. The most studied and inhibited was nitrification (25-100\%) mainly at therapeutic doses, and rarely to environmentally relevant.

We recommend that firm conclusions regarding inhibition of antibiotics at environmentally relevant concentrations remain difficult due to the lack of studies testing low concentrations at chronic exposure. There is thus a need to test the effects of these environmental concentrations on biogeochemical processes to further establish the possible effects on ecosystem functioning. ecotoxicology 
Since their discovery in the 1930s, antibiotics have considerably improved human and animal health and agricultural yields. However, their over-use soon caused problems such as ineffectiveness on pathogenic bacteria (Finley et al. 2013) due to the accelerated development of antibiotic resistant bacteria. Moreover, most antibiotics are not metabolized and are released into the environment via urine and feces. Concentrations of antibiotics can reach several $\mathrm{mg} / \mathrm{kg}$ of sediment, especially in aquatic ecosystems downstream of manufacturing plants (see review in Larsson et al. 2014) or aquaculture farms (e.g. Rico et al., 2014). Even in other environments such as river water or sediment, antibiotics often occur at concentrations from $\mathrm{ng} / \mathrm{L}$ to $\mu \mathrm{g} / \mathrm{L}$ or $\mu \mathrm{g} / \mathrm{kg}$. These environmentally concentrations are generally too low to inhibit bacterial activity. On the contrary, inhibitory concentrations (see definition in Nordberg et al. 2009) are often referred to as therapeutic concentrations $(\geq 1 \mathrm{mg} / \mathrm{L}$ ). The effects of environmentally relevant concentrations of antibiotics can fundamentally differ from therapeutic concentrations, enhancing bacterial communication or transcription regulation (Andersson and Hughes 2014, Davies and Ryan 2012). While many unknowns concerning chronic exposure to low doses remain, there is concern that low doses may favor and sustain genes for antibiotic resistance in the environment (Allen et al. 2010, Kümmerer 2009b).

Although antibiotics have been detected in many environments, their ecological effects have been poorly investigated, particularly concerning non-target bacteria and their related ecological functions. Antibiotics target bacteria by preventing their growth (bacteriostatic) or killing them (bactericidal). Antibiotics can be natural (i.e. produced by micro-organisms in their own habitat) or of synthetic origin. Most antibiotics target one of three bacterial functions: cell-wall biosynthesis, protein synthesis, or DNA replication and repair. Some antibiotics affect a wide range of pathogens (broad spectrum) while others specifically target a group of bacteria (e.g. Gram-positive bacteria). At the level of an individual bacterium, antibiotic-resistance can develop by: (1) pumping out the antibiotic, (2) destroying the active compounds of the antibiotic, (3) reprograming (or camouflaging) the target structure (Schmieder and Edwards 2012). At the ecosystem level (i.e. soil, sediment or water), the microbial community and physical habitat can respond to antibiotic exposure or modulate its effects, with large physicochemical differences between ecosystems and consequently strong differences in response to antibiotic exposure. Ecosystems such as soils are extremely physicochemically complex and dynamic, supporting high microbial diversity. Abiotic inactivation of the antibacterial molecules can occur before ever reaching bacteria by interactions with soil organo-mineral compounds (e.g. clays), organic matter (Conkle and White, 2012), or reactions such as photodegradation or hydrolysis (Thiele-Bruhn, 2003). A lack of antibiotic effect can be due to antibiotic physicochemical properties such as a strong sequestration and low bioavailability (Rosendahl et al. 2012) and thus depends on the type of environmental matrix (solid or liquid). The antibiotic tolerance of a bacterial community, or more specifically of a bacterial function, may involve a shift in the community structure (composition, richness, density) or depend on the spatial distribution of members of the community. Bacterial biofilms, made up of an aggregation of microbes of different species surrounded by extracellular polymers, are more tolerant than planktonic bacteria because polymers are resistant to penetration of toxic compounds (Campos et al. 2001; Stewart 2002). Furthermore the more tolerant bacteria in the biofilm benefit from the exposure and become the dominant members of the community (Knapp et al. 2008) or tolerant 
bacteria may develop on the dead remains of the biofilm (Kotzerke et al. 2011, Demoling et al. 2009, Kleineidam et al. 2010, Reichel et al. 2013, Yergeau et al. 2012).

Natural microbial communities are characterized by a large functional redundancy, with multiple species able to carry out the same process. Functional redundancy can allow a process to continue during antibiotic exposure despite modifications in community structure. Bacterial communities can also adapt quickly on hourly or monthly time-frames. Only a few studies have considered both the effects on antibiotic exposure on community structure and ecosystem functioning via process rates (Näslund, et al. 2008, Roose-Amsaleg et al. 2013, Underwood et al. 2011, Wunder et al. 2013, Yamamura et al. 2014).

Biogeochemical functioning of ecosystems relies largely on microbial activity, with ecosystem services such as nutrient cycling, organic matter production and turnover or degradation of pollutants regulated by microbial metabolism (Ducklow 2008). In this mini-review we investigated how environmentally relevant antibiotic concentrations affect biogeochemical functioning and thus disturb ecosystem processes. We were interested to know if antibiotics have environmental side-effects in addition to inducing and sustaining antibiotic resistance. Studies exploring effects of antibiotics on the microbial community structure and biomass will not be discussed here, only those investigating the side-effect on a biogeochemical process. We first briefly described the fate of antibiotics in the environment and the known microbiological effects of antibiotics, and then provide an overview of the impact of antibiotics on biogeochemical processes. In the last section we assessed the effects of antibiotics on the three major processes of the nitrogen cycle: nitrification, denitrification and anammox. We discussed both acute and chronic antibiotic exposures, though we focused on the latter since it is more environmentally representative. We did not include tests directly conducted on purified enzymes, as the effect on enzyme activity is distinct from the effect of antibiotics on bacterial growth or life. We concluded that future studies should include both community analysis and process rates measurements, in order to establish a mechanistic relationship and explain the effects on biochemical processes mediated by antibiotic exposure.

\section{Antibiotics in the environment}

In the last 20 years, improved analytical capabilities have allowed the detection of antibiotic residues in virtually all natural habitats (Bell et al. 2013, Kümmerer 2009a, Thiele-Bruhn 2003). At least 1,500 publications have addressed antibiotic molecules in the environment. Similarly, the spread of antibiotic resistance in hospitals and in the environment has been extensively discussed and studied with over 850 publications. Many of the studies report an inventory of antibiotic resistance genes (Nesme et al. 2014) and many address bacteria in aquatic environments (for review see Kümmerer 2009b) or soils (Gatica and Cytryn 2013). The resistance of bacterial species used as fecal indicators was also often investigated (Luczkiewicz et al. 2013, Servais and Passerat 2009). However, despite the proliferation of environmental antibiotic studies in general, relatively few have considered the impact of antibiotics on "ecosystem health" (Gu 2014). 
Regarding the effects of antibiotics in the environment, two aspects have to be considered: (1) the type of bacteria exposed to antibiotics in the environment and (2) the range of antibiotic concentrations to which these bacteria are exposed. While antibiotics can be lethal for pathogenic bacteria, little is known regarding their toxicity on microorganisms that are not the intended targets of a particular antibiotic (Nordberg et al. 2009). These non-target organisms comprise the majority of bacteria inhabiting natural environments. The vulnerability of bacteria to antibiotics is evaluated by measuring the minimum inhibitory concentration (MIC) (Andersson and Hughes 2014). A list of antibiotic MIC exists for bacteria and antibiotics of medical interest (European Committee on Antimicrobial Susceptibility Testing, data from the EUCAST MIC distribution website, last accessed 24 March 2015. http://www.eucast.org). Because more than 99\% of environmental bacteria are not able to be cultured (Amann et al. 1995) their MIC cannot be measured. Furthermore MIC measures acute lethal toxicity (Nordberg et al. 2009), the effect of high levels over short-term periods as revealed by mortality (Crane et al. 2006), of a single strain of a particular species. This strongly contrasts natural environments where chronic exposure occurs over long periods, sometimes representing a substantial portion of a microbial community's lifespan and toxicity is measured by observing mortality, growth or reproduction (Nordberg et al. 2009).

Exposure to therapeutic levels of antibiotics can favor resistant phenotypes, representing a serious public health hazard. However, in environmentally relevant concentrations, vulnerable strains can continue to grow, though sometimes at a reduced rate (Andersson and Hughes, 2014). Though some studies have extrapolated the effects of acute, high doses of antibiotics, there are likely non-linear thresholds and emergent behavior of sub-inhibitory doses in the environment. Sub-inhibitory doses of antibiotics can select for bacterial resistance in vitro originating from both enrichment of pre-existing antibiotic resistant bacteria and from selection of de novo resistant bacteria (Andersson and Hughes, 2014). These doses further cause the acceleration and spread of resistance in bacteria affecting humans and animals. Sub-inhibitory levels of antibiotic on bacterial physiology can cause mutagenesis, virulence, biofilm formation, and horizontal gene transfer recombination, at least in vitro. Furthermore, environmentally relevant concentrations of antibiotics ranging from ng- $\mu \mathrm{g} / \mathrm{L}$ or $/ \mathrm{kg}$ could act as signaling molecules involved in quorum sensing biofilm formation and virulence (Andersson and Hughes 2014).

\section{Effects on biogeochemical processes}

The consequences of antibiotics on biogeochemical processes are still not well-documented. To the present date (2015, March), we found 31 articles (Table 1) exploring effects of antibiotics on these processes. Identifying general patterns was complicated by the fact that there is no single standardized method to study the effect on biogeochemical processes. Nevertheless, a common way to study antibiotic effects on biogeochemical processes is to reproduce in the laboratory a simple system and then controlling several parameters, notably the antibiotic exposure. Depending on the nature of the environmental sample, different laboratory tests are used, such as batches (homogenization of the sample) or microcosms (intact soil or sediment incubation; Underwood et al. 2011, Yan et al. 2013). Mesocosms and field trials are less often used due to the complexity of their set up (Rosendahl et al. 2012) even though they tend to better reflect chronic exposure conditions in the environment. 
We found 12 studies from natural aquatic environments, six from waste water treatment plants (WWTP), eight from soils, and five on bacterial enrichments. $77 \%$ of these studies included processes involved in the nitrogen cycle. The non-nitrogen-related studies involved sulfate-reduction (Hansen et al. 1992, Ingvorsen et al. 2003, Liu et al. 2014), pyrene degradation (Näslund et al.2008), iron reduction (Thiele-Bruhn and Beck 2005, Toth et al. 2011), arsenic oxidation and reduction (Yamamura et al. 2014), methanogenesis (Conkle and White 2012, Fountoulakis et al. 2004, Liu et al. 2014), and acetate biodegradation kinetics (Wunder et al. 2013). We only found a few studies that examined the effect of antibiotics on several biogeochemical processes (Conkle and White 2012, Kotzerke et al. 2008, Kotzerke et al. 2011, Liu et al. 2014, Rosendahl et al. 2012, Toth et al. 2011).

The 12 studies tested a total of 14 antibiotic families with 31 compounds displaying extremely different physicochemical properties that cause differences in target species and antibiotic mechanisms. In the following sections we give a brief overview of the experimental procedure of exposure concentrations and experimental design to compare and review the effects of antibiotics on biogeochemical processes.

Across studies, the fate of the antibiotic substance during the experiment was often unconsidered and only $40 \%$ of the studies quantified the antibiotic concentration in the experimental medium to determine the effect on a certain process (Ahmad et al. 2014, Campos et al. 2001, Hansen et al.1992, Hou et al. 2015, Kotzerke et al. 2008, Kotzerke et al. 2011, Liu et al. 2014, Rico et al. 2014, Roose-Amsaleg et al. 2013, Rosendahl et al. 2012, Thiele-Bruhn and Beck 2005, Yan et al. 2013). Regardless the antibiotic family, these studies revealed considerable loss of antibiotics over the experiment. In the environment, antibiotic degradation includes diverse processes such as biodegradation, evaporation, and sorption to organic matter. For studies where it was reported, antibiotic concentrations decreased by 62 to $100 \%$ during the experiments: $66-100 \%$ in soil (Kotzerke et al. 2008), 62-93\% in sediment (Yan et al. 2013), and 64-98\% in water (Rico et al. 2014). Although antibiotics have low volatilities and do not tend to bioaccumulate, they show variable adsorption capacities and decay rates (halflives from hours to months and even to years in a solid matrix). Sorption coefficients of the 14 antibiotics ranged from high (oxolinic acid) to low (sulfamethoxazole) in the 12 studies. Continuous addition of antibiotic could compensate for the antibiotic degradation observed in all studies. Otherwise studies should consider both nominal and measured antibiotic concentrations to determine whether the degradation rates observed in the laboratory and semi-field experiments provide sufficient antibiotic exposure.

We assessed whether acute or chronic toxicity was studied though it was rarely explicitly mentioned, (see Table 1). We considered the duration of the experiment, the type of antibiotic supply, and the antibiotic concentration of the exposure.

\section{Duration of the experiments: short-term versus long-term effects}

One of the first studies investigating the effect of antibiotics on a functional trait (denitrification) was short-term, on the scale of hours (Costanzo et al. 2005). Short exposure time is problematic for slow-growing bacteria. Generation times of known cultivated ammonia-oxidizing bacteria vary from 8 to 138 hours with a common value of 20 hours (Prosser 1989) and the doubling time of anammox bacteria is 9 days (Strous et al.1999). Under optimal conditions the doubling time for denitrifiers varies between 1.5-1.9 hours ( $P$. denitrificans and P. Stutzeri, Carlson and Ingraham, 1983). However the doubling time of heterotrophic microorganisms in soils is $\sim 9$ days (Baath et al. 1988). Acute toxicity tests regularly last hours rather than days 
or weeks. The duration of the exposure of colistin used by Bressan et al. (2013) on ammonia-oxidizing bacteria was 5 h. Schmidt et al. (2012) already stated that "inhibition of cell division or protein biosynthesis may be observed only after test duration of several days". The importance of incubation time was also shown in the "Substrate Induced Respiration (SIR)" test of Thiele-Bruhn and Beck (2005); no effect was observed after 4 h, whereas respiration was inhibited by both oxytetracycline and sulfapyridine, after $24 \mathrm{~h}$. Short-term experiments that are shorter than the growth rate of the targeted bacteria, therefore, explore the effect of the antibiotic on enzyme activity. Studies regarding short-term effects (Bressan et al. 2013, Costanzo et al. 2005, Hou et al. 2015, Katipoglu-Yazan et al. 2013) can be contrasted to long-term effect studies: from days (Ahmad et al. 2014, Alighardashi et al. 2009, Conkle and White 2012, Fountoulakis et al. 2004, Hou et al. 2015, Ingvorsen et al. 2003, Thiele-Bruhn and Beck 2005, Yamamura et al. 2014), weeks (Campos et al. 2001, Cui et al. 2014, Klaver and Matthews 1994, Kotzerke et al. 2008, Kotzerke et al. 2011, Lotti et al. 2012, Rico et al. 2014, RooseAmsaleg et al. 2013, Toth et al. 2011, Underwood et al. 2011, Wunder et al. 2013, Yan et al. 2013), months (Fernandez et al. 2009, Hansen et al. 1992, Näslund et al. 2008, Rosendahl et al. 2012) to year (442 days by Schmidt et al. 2012). Conducting experiments for extended time periods is difficult because degradable antibiotics, as well as nutrients can be quickly consumed unless continuously added (Aligardashi et al. 2009).

\section{Supply of antibiotic}

In most studies (25 out of 31), the antibiotic was added once or several times (Campos et al. 2001; Fernandez et al. 2009; Rico et al. 2014; Schmidt et al. 2012). Only three studies continuously supplied the antibiotic (Wunder et al. 2013, Yan et al. 2013; Roose-Amsaleg et al. 2013). With a single antibiotic addition, the exposure might be insufficient and a lack of effect can be confounded with a lack of exposure of the antibiotic due to degradation. Among the 24 studies using a single addition of the antibiotic, eight quantified the antibiotic. The chronic exposure cannot be ascertained in the other cases. In order to be sure of the exposed and effective antibiotic levels, these should be measured over the course of the experiment.

\section{Level of exposure}

Most studies investigating the effect on biogeochemical process used an antibiotic exposure which is therapeutic $(\mathrm{mg} / \mathrm{L}$ or $\mathrm{mg} / \mathrm{kg}$ ), thus higher than those found in polluted environments. These high concentrations of antibiotic could be used as a positive control in the experiments, but a larger range of antibiotic concentrations, including environmentally relevant ones should be tested. However over half of the studies (17 of 31) exclusively tested those therapeutic levels which do not reflect environmental exposures. Inhibitive effects were almost always observed in those studies but were sometimes reversible (Hansen et al. 1992) or temporary (Kotzerke et al. 2011). Among the five antibiotics tested at $1 \mathrm{mg} / \mathrm{L}$ by Costanzo et al. (2005), three inhibited (erythromycin, clarithromycin, amoxicillin), whereas two (ciprofloxacin and the mixture amoxicillin and clavulanic acid) did not inhibit denitrification. Similarly, Campos et al. (2001) did not observe any inhibition for one among two antibiotics (chloramphenicol) on nitrification even when applied at 10-250 mg/L. However as explained by Alighardashi et al. (2009) the use of high levels of antibiotic is appropriate when batch experiments are carried out, notably on wastewater.

As a conclusion given by Alighardashi et al. (2009), long-term "laboratory-scale" studies using low antibiotic concentrations should be complemented by short-term "batch" experiments that use large doses. 

chronic in order to give relevant results. Effects of environmentally relevant concentrations on processes need further study, with particular attention to incubation period, the antibiotic of interest, and the environmental matrix.

Studies on the effects of cocktails or mixtures of antibiotics on biogeochemical processes are even scarcer but of growing concern (Ingvorsen et al. 2003, Schmidt et al. 2012; Wunder et al. 2013). The positive synergistic effect of an antibiotic mixture on the model organism Vibrio Fisheri has been demonstrated by Backhaus et al. (2000). Although the low doses of each antibiotic were not toxic individually, the mixture was strongly toxic. A study carried out with a combination of environmentally relevant concentrations $(\mu \mathrm{g} / \mathrm{L})$ showed that the simultaneous exposure to three antibiotics (sulfamethoxazole, ciprofloxacin, and erythromycin) had no effect on the degradation of acetate (Wunder et al. 2013). The two other studies tested therapeutic concentrations of antibiotic mixtures and observed expected inhibition. Schmidt et al. (2012) explored the effect of a mixture of ciprofloxacin, gentamycin, sulfamethoxazole, trimethoprim, and vancomycin $(0.1-40 \mathrm{mg} / \mathrm{L})$ on chemical oxygen demand and nitrification. The chosen experimental setup for their study simulated conditions of a waste water treatment plant, nitrification was completely inhibited at $40 \mathrm{mg} / \mathrm{L}$. They concluded that typical conditions in a treatment plant would not result in suppression of nitrogen removal. Similarly, Ingvorsen et al. (2003) showed a strong inhibition (90\%) of sulfate reduction after a high dose of chloramphenicol and streptomycine, 20 and 100 $\mathrm{mg} / \mathrm{L}$, respectively.

In the natural environment, multiple antibiotics are present as mixtures. Individual antibiotic applications reveal potential mechanisms of inhibition, whereas to determine realistic effects on processes, mixtures should be investigated. In the future, studies regarding this mixture and possible synergistic effect should be considered (notably using existing concepts for the prediction of mixture toxicities, Backhaus et al. 2000). Studying multiple antibiotics at environmentally relevant concentrations as well as the possible role of other contaminants (e.g. metals or pesticide) should be tested.

\section{Effect of antibiotics on nitrogen cycle}

The following sections specifically examine the three most studied biogeochemical processes in the nitrogen cycle: nitrification, anammox, and denitrification. They represent distinct processes in regard to metabolism and microbes. Bacterial denitrification is almost always facultative (Zumft 1997) in contrast to anammox and denitrification. Although denitrifiers form a phylogenetically diverse group (Philippot and Hallin 2005) spread among three kingdoms, microorganisms involved in nitrification or anammox have much lower phylogenetic diversity. This difference might affect their vulnerability to antibiotic exposure, with multi-species communities showing higher resilience to antibiotics (Näslund et al. 2008). Furthermore, both nitrifiers and anammox bacteria have single cellular organizations entailing different responses to antibiotic exposure. Nitrification is carried out in two steps by both Gram-negative bacteria (Kowalchuck and Stephen, 2001) and Archaea (Treusch et al. 2005) during ammonia-oxidation and only by Gram-negative bacteria during the nitrite 
oxidation (Spieck and Lipski 2011). Archaea are less sensitive to antibiotics than bacteria due to differences in

271 cell envelopes and metabolic processes (Shen et al. 2013). For example, the ammonia oxidizing archaea

272 Nitrososphaera viennensis is resistant to streptomycin, kanamycin, ampicillin, and carbenicillin (Tourna et al.

273 2011). Similarly the anammox bacteria, all members of the order Planctomycetales (Strous et al., 1999) are

274 known for their unique membrane lipids. Furthermore, planctomycetes do not have murein in their cell walls, a

275 target of several antibiotics, and are thus resistant towards these compounds (Claus et al. 2000). Furthermore, the

276 anammox process is carried out within an internal organel, the anammoxosome, which may protect the activity

277 from the effects of antibiotics. Among the studies testing antibiotics on $\mathrm{N}$ transformations, thirteen publications

278 studied the effect of antibiotics on nitrification, twelve on denitrification, and two on anammox. 
Nitrifiers have been used to determine the effect of antibiotics on nitrification. The ISO 9509 norm tests toxicity by assessing the inhibition of nitrification of activated sludge microorganisms (Juliastuti et al. 2003). Nitrifiers are highly sensitive to inhibitory compounds (including antibiotics) in aerobic environments. Furthermore nitrifiers are used as biosensors to detect the toxicity of molecules present in waste water treatment plants (Alighardashi et al. 2009, Carucci et al. 2006).

Out of the 13 studies, nine showed an effect of antibiotics out of which only four (four antibiotics) did not inhibit nitrification, confirming the high sensitivity of nitrifiers at therapeutic antibiotic concentrations. There was no measured inhibition (1) of soil nitrifiers in the studies involving antibiotic-spiked manure added to soil (Toth et al. 2011, Rosendahl et al. 2012) with monensin and difloxacin, respectively; (2) of mixed nitrifying cultures by chloramphenicol (Campos et al. 2001); (3) of ammonia-oxidizers from a mixed culture of nitrifying bacteria by colistin (Bressan et al. 2013). The latter study observed that nitrite-oxidizing bacteria were more susceptible to colistin than ammonia-oxidizers. Except the physicochemical behavior of the antibiotic, Campos et al. (2001) explained the lack of inhibition by a shift in ammonia-oxidizing bacteria (AOB) versus ammoniaoxidizing archaea (AOA). This is in agreement with Schauss et al. (2009) who calculated via modeling an EC50 strongly higher for AOA compared to AOB for sulfadiazine.

Among the studies showing an effect, only three tested both environmentally relevant and therapeutic concentrations (Rico et al. 2014, Toth et al. 2011, Schmidt et al. 2012). Rico et al. (2014) carried out a chronic exposure of tropical freshwater to a fluoroquinolone (enrofloxacin) in a microcosm. An inhibitive effect of this antibiotic above $100 \mu \mathrm{g} / \mathrm{L}$ was demonstrated whereas they measured NOEC (No-Observed-Effect-Concentration see Nordberg 2009, for definition) of 10 and $1 \mu \mathrm{g} / \mathrm{L}$ from bacterial and archaeal ammonia-oxidizer abundance, respectively. They actually observed a relation between nitrification activity and an antibiotic exposure at 1,000 $\mu \mathrm{g} / \mathrm{L}$, which is above environmentally relevant concentration. They explained this by the "high resilience of the whole water-sediment microbial community and a fast recovery from antibiotic exposure". Toth et al. (2011) measuring only the production of $\mathrm{NO}_{2}{ }^{-}$on soil chronically exposed to manure spiked with a sulfonamide (sulfadimethoxin) observed inhibition of ammonia-oxidation until $200 \mu \mathrm{g} / \mathrm{kg}$.

To conclude 14 out of the 16 tested antibiotics inhibited nitrification in the environment at therapeutic levels: sulfadiazine, oxytetracycline, ofloxacin, sulfamethoxazole, erythromycin, ciprofloxacin, gentamicin, colistin, trimethoprim, vancomycin, sulfadimethoxine, enrofloxacine, difloxacin, and tetracycline. The inhibition of such therapeutic antibiotic concentrations could entail severe efficiency loss from $25 \%$ (sulfadiazine, in soils at $100 \mathrm{mg} / \mathrm{kg}$; Kotzerke et al 2008) to the complete inhibition of nitrification (all in WWTP; see the antibiotic mixture of Schmidt et al. 2012, tetracycline or erythromycin see in Katipoglu-Yazan et al, 2013). Overall environmental relevant concentrations of fluoroquinolones alone or in mixtures were able to inhibit nitrification rates in environmental samples but the majority of the studies tested therapeutic levels. 
Denitrification comprises four enzymatic steps involving heterotrophic, facultatively anaerobic microorganisms. However, the effect of antibiotics on the first step (i.e. nitrate reduction and nitrite production) was primarily studied while nitrous oxide production was rarely measured (Hou et al. 2015 and Roose-Amsaleg et al. 2013). Acute or chronic effects of several antibiotics on denitrification were studied using therapeutic levels (Costanzo et al. 2005; Murray and Knowles, 1999; Kotzerke et al. 2008, 2011). Recently, environmentally relevant antibiotic concentrations have been tested in eight studies. Denitrification rates were inhibited at environmentally relevant doses of sulfamethoxazole (sulfonamide) in soils (Conkle and White 2012; $500 \mu \mathrm{g} / \mathrm{kg}$ ) and groundwater (Underwood et al. 2011, $\mu \mathrm{g} / \mathrm{L}$ ), whereas nitrate reduction rates were not affected in river sediments (Yan et al. 2013; $10 \mu \mathrm{g} / \mathrm{L}$ ). An accumulation of nitrite was observed at low concentrations of sulfamethoxazole in the sediment (Yan et al. 2013), suggesting a negative effect of this antibiotic on the microbial community reducing nitrite to nitrous oxide and nitrogen gas. This supports the theory that a less diverse community is more vulnerable than a diverse one. The reduction of oxidized nitrogen species further to gaseous from is carried out by fewer organisms than nitrate reduction (Zumft 1997). Among the other antibiotics tested at environmentally relevant concentrations, only sulfamethazine was able to inhibit denitrification at environmentally relevant concentrations (Ahmad et al. 2014, groundwater, $10 \mu \mathrm{g} / \mathrm{L}$; Hou et al. 2015, sediment, $50 \mathrm{ng} / \mathrm{L}$ ). All this suggests that sulfonamides (sulfamethoxazole and sulfamethazine) could represent a risk for the ecosystem health at levels detected in natural habitats, as a widespread, broad-spectrum antibiotic with a low sorption potential (Conkle and White, 2012). The denitrification inhibitions measured ranged from 17 to $82 \%$ but never completely blocked the denitrification process.

Bacteria responsible for the anammox process express several typical cellular traits such as (1) singleor double-membrane-bounded compartments separating their chromosome from the remainder of the cytoplasm, (2) peptidoglycan-free cell walls (Strous et al. 1999), able to adapt to antibiotics. We would expect anammox bacteria to be more resistant to antibiotics due to their different cell structure, though this depends on the mode of action of the antibiotic (e.g. they are insensitive to ampicillin; Strous et al. 1999).

Two studies (Fernandez et al. 2009; Lotti et al. 2012) investigated the effect of antibiotics on the anammox process exploring both acute and chronic effects of four different antibiotics (oxytetracycline, tetracycline hydrochloride, sulfathiazole and chloramphenicol). Only therapeutic concentrations $(100-1,000 \mathrm{mg} / \mathrm{L})$ were tested in WWTP sludges. The anammox process was inhibited in all the assays regardless of the duration of exposure.

Anammox plays an important role in WWTPs as well as in natural environments (e.g. Dalsgaard et al. 2005). Further study should therefore focus on high-risk areas such as recipients of animal farm wastewater or facilities. 


\section{Conclusions and perspectives}

354

Data on the sources, fate, and effects of antibiotics in the environment, indicate that antibiotics may alter several biogeochemical cycles. In addition to being a threat to public health, antibiotics represent a threat to ecosystem functioning and health, even if their toxic effect could often be buffered in complex and diverse ecosystems. Regarding the existing bibliography, antibiotics such as fluoroquinolones or sulfonamides appear as the most noxious compounds among all families of antibiotics. However these molecules were also the most tested, biasing this preliminary conclusion. Furthermore among the different microbial processes in nitrogen cycling, nitrification and anammox appear to be less sensitive to antibiotic exposure (sensitivity at therapeutic concentrations) than denitrification.

In addition to 'ecosystem health', there is a concern regarding the impact of antibiotics on ecosystem services delivered by environmental bacteria. Though the data gathered in this mini-review do not allow identifying certain molecules to inform usage recommendations, they clearly demonstrate the importance of further investigation of the effects of antibiotics on biogeochemical processes at environmentally relevant concentrations. It should be noted that from a regulatory perspective, environmental effects of pharmaceuticals are not considered in any way in practice. It is crucial to consider the antibiotic impacts on environments such as the accumulation of nitrite in aquatic environments or of nitrous oxide (a strong greenhouse effect gas) due to a possible inhibition of nitrification or denitrification. In watersheds, wetlands, or waste water treatment plants with clear management priorities regarding nitrogen pollution, small effects of antibiotics on nitrogen removal might be very important. So far, establishing the effect of environmentally relevant antibiotic concentrations on processes is not standardized and results are contradictory (see Table 1).

A more standardized approach testing the effect of environmentally relevant concentrations of antibiotic at chronic levels (simulating in situ conditions) on more or less sensitive biogeochemical functions is needed to allow comparison between studies. We propose that future studies investigating the exposure of antibiotics on biogeochemical processes include chronic exposure, either via continuous supply of antibiotics or repeated additions. Furthermore experimental design in aquatic systems can involve a mixed batch set-up mimicking environmental conditions. The effect of antibiotics in soil or sediments should preferably be carried out in microcosm, mesocosm, or field studies. In the latter, a survey of the administered compounds is recommended to rank antibiotics regarding their increasing ecological impact to allow the prioritization of regulation depending on different usages. Besides the type of antibiotic, other biogeochemical processes should be considered, in addition to $\mathrm{N}$ cycling processes, such as those involved in metal transformation or degradation of pollutants. Furthermore, case studies investigating the effect of antibiotics on biogeochemical processes should determine the effect of these pharmaceuticals at a larger scale, involving a comprehensive interdisciplinary approach, including hydrology (transport), chemistry (nutrients, pollutants, and pharmaceuticals), and biology (process rates and involved organisms). 
391 The authors acknowledge the constructive comments of four journal reviewers and Ben Abbott for proofreading 392 the paper. 
Ahmad M, Vithanage M, Kim K, Cho J-S, Lee YH, Joo YK, Lee SS, Ok YS (2014) Inhibitory effect of

396

397

398

399

400

401

402

403

404

405

406

407

408

409

410

411

412

413

414

415

416

417

418

419

420

421

422

423

424

425

426

427

428

429

430

431 veterinary antibiotics on denitrification in groundwater: A microcosm approach. ScientificWorldJournal. doi: 10.1155/2014/879831.

Alighardashi A, Pandolfi D, Potier O, Pons MN (2009) Acute sensitivity of activated sludge bacteria to erythromycin. Journal of Hazardous Materials 172, 685-692. doi: 10.1016/j.jhazmat.2009.07.051.

Allen HK, Donato J, Wang HH, Cloud-Hansen KA, Davies J, Handelsman J (2010) Call of the wild: antibiotic resistance genes in natural environments. Nat Rev Microb 8, 251-259. doi: 10.1038/nrmicro2312.

Allers T, Mevarech M (2005) Archaeal genetics - The third way. Nat Rev Genet 6 (1) 58-73. doi: $10.1038 / \mathrm{nrg} 1504$.

Amann RI, Ludwig W, Schleifer KH (1995) Phylogenetic identification and in situ detection of individual microbial cells without cultivation. Microbiol Rev 59, 143-69.

Andersson DI, Hughes D (2014) Microbiological effects of sublethal levels of antibiotics. Nat Rev Microb 12, 465-478. doi: 10.1038/nrmicro3270.

Baath E, Olsson S, Tunlid A (1988) Growth of bacteria in the rhizoplane and the rhizosphere of rape seedlings. FEMS Microbiol Ecol 53 (6) 355-360. doi: 10.1016/0378-1097(88)90501-0.

Backhaus T, Altenburger R, Boedeker W, Faust M, Scholze M, Grimme L H (2000) Predictability of the toxicity of a multiple mixture of dissimilarly acting chemicals to Vibrio fischeri. Environ Toxicol Chem 19 (9) 2348-2356. doi: 10.1897/1551-5028(2000)019<2348:pottoa>2.3.co;2.

Bell KY, Bandy JJ, Finnegan BJ, Keen O, Mauter MS, Parker AM, Sima LC, Stretz HA (2013) Emerging Pollutants - Part II: Treatment. Water Environ Res 85, 2022-2071. doi: $10.2175 / 106143013 \times 13698672323308$.

Bressan CR, Kunz A, Schmidell W, Soares HM (2013) Toxicity of the colistin sulfate antibiotic used in animal farming to mixed cultures of nitrifying organisms. Water Air Soil Poll 224 (3), 1-9. doi: 10.1007/s11270-013-1441-4.

Carlson C A, Ingraham J L (1983) Comparison of denitrification by Pseudomonas stutzeri, Pseudomonas aeruginosa and Pseudomonas denitrificans. Appl Environ Microb 45 (4) 1247-1253.

Campos JL, Garrido JM, Mendez R, Lema JM (2001) Effect of two broad-spectrum antibiotics on activity and stability of continuous nitrifying system. App Biochem Biotech 95, 1-10. doi: 10.1385/abab:95:1:01.

Carucci A, Cappai G, Piredda M (2006) Biodegradability and toxicity of pharmaceuticals in biological wastewater treatment plants. J Environ Sci Heal A 41, 1831-1842. doi: 10.1080/10934520600779000.

Claus H, Martin HH, Jantos CA, Konig H (2000) A search for beta-lactamase in chlamydiae, mycoplasmas, planctomycetes, and cyanelles: Bacteria and bacterial descendants at different phylogenetic positions and stages of cell wall development. Microbiol Res 155, 1-6.

Conkle JL, White JR (2012) An initial screening of antibiotic effects on microbial respiration in wetland soils. J Environ Sci Heal A 47, 1381-1390. doi: 10.1080/10934529.2012.672315.

Cordova-Kreylos AL, Scow KM (2007) Effects of ciprofloxacin on salt marsh sediment microbial communities. ISME J 1, 585-595. doi: 10.1038/ismej.2007.71. 
Costanzo SD, Murby J, Bates J (2005) Ecosystem response to antibiotics entering the aquatic environment. Mar Pollut Bull 51, 218.

Crane M, Watts C, Boucard T (2006) Chronic aquatic environmental risks from exposure to human pharmaceuticals. Sci Total Environ 367, 23-41. doi: 10.1016/j.scitotenv.2006.04.010.

Cui H, Wang S P, Fu J, Zhou Z Q, Zhang N, Guo L (2014) Influence of ciprofloxacin on microbial community structure and function in soils. Biol Fert Soils 50 (6) 939-947. doi: 10.1007/s00374-014-0914-y.

Dalsgaard T, Thamdrup B, Canfield D E (2005) Anaerobic ammonium oxidation (anammox) in the marine environment. Res Microbiol 156 (4) 457-464. doi: 10.1016/j.resmic.2005.01.011.

Davies J, Ryan KS (2012) Introducing the parvome: Bioactive compounds in the microbial world. Acs Chem. Biol. 7, 252-259. doi: 10.1021/cb200337h.

Demoling LA, Baath E, Greve G, Wouterse M, Schmitt H (2009) Effects of sulfamethoxazole on soil microbial communities after adding substrate. Soil Biol Biochem 41, 840-848. doi: 10.1016/j.soilbio.2009.02.001.

Ducklow H (2008) Microbial services: challenges for microbial ecologists in a changing world. Aquat Microb Ecol 53, 13-19. doi: 10.3354/ame01220.

Fernandez I, Mosquera-Corral A, Campos JL, Mendez R (2009) Operation of an Anammox SBR in the presence of two broad-spectrum antibiotics. Process Biochem 44, 494-498. doi: 10.1016/j.procbio.2009.01.001.

Finley RL, Collignon P, Larsson DGJ, McEwen SA, Li XZ, Gaze WH, Reid-Smith R, Timinouni M, Graham DW, Topp E (2013) The scourge of antibiotic resistance: The important role of the environment. Clin Infect Dis 57, 704-710. doi: 10.1093/cid/cit355.

Fountoulakis M, Drillia P, Stamatelatou K, Lyberatos G (2004) Toxic effect of pharmaceuticals on methanogienesis. Wa Sci Technol 50 (5) 335-340.

Gatica J, Cytryn E (2013) Impact of treated wastewater irrigation on antibiotic resistance in the soil microbiome. Environ Sci Polluti R 20, 3529-3538. doi: 10.1007/s11356-013-1505-4.

Gu JD (2014) Assessment of ecosystem health and ecotoxicology through chemical analysis and modeling. Ecotoxicology 23, 475-479. doi: 10.1007/s10646-014-1206-x.

Hansen PK, Lunestad BT, Samuelsen OB (1992) Effects of oxytetracycline, oxolinic acid, and flumequine on bacteria in an artificial marine fish farm sediment. Can J Microbiol 38, 1307-1312.

Hou L, Yin G, Liu M, Zhou J, Zheng Y, Gao J, Zong H, Yang Y, Gao L, Tong C (2015) Effects of sulfamethazine on denitrification and the associated $\mathrm{N}_{2} \mathrm{O}$ release in estuarine and coastal sediments. Environ Sci Technol 49, 326-33. doi: 10.1021/es504433r.

Ingvorsen K, Nielsen MY, Joulian C (2003) Kinetics of bacterial sulfate reduction in an activated sludge plant. FEMS Microbiol Ecol 46, 129-137.

Juliastuti S R, Baeyens J, Creemers C (2003) Inhibition of nitrification by heavy metals and organic compounds: The ISO 9509 test. Environ Eng Geosci 20 (2) 79-90. doi: 10.1089/109287503763336511.

Klaver AL, Matthews RA (1994) Effects of oxytetracycline on nitrification in a model aquatic system. Aquaculture 123, 237-247.

Katipoglu-Yazan T, Pala-Ozkok I, Ubay-Cokgor E, Orhon D (2013) Acute impact of erythromycin and tetracycline on the kinetics of nitrification and organic carbon removal in mixed microbial culture. Bioresource Technol 144 410-419. doi: 10.1016/j.biortech.2013.06.121. 
Kleineidam K, Sharma S, Kotzerke A, Heuer H, Thiele-Bruhn S, Smalla K, Wilke BM, Schloter M (2010) Effect of sulfadiazine on abundance and diversity of denitrifying bacteria by determining nirK and nirS genes in two arable soils. Microb Ecol 60,703-707. doi: 10.1007/s00248-010-9691-9.

Knapp CW, Engemann CA, Hanson ML, Keen PL, Hall KJ, Graham DW (2008) Indirect evidence of transposon-mediated selection of antibiotic resistance genes in aquatic systems at low-level oxytetracycline exposures. Environ Sci Technol 42, 5348-5353. doi: 10.1021/es703199g.

Kotzerke A, Fulle M, Sharma S, Kleineidam K, Welzl G, Lamshoft M. Schloter M, Wilke BM (2011) Alterations in total microbial activity and nitrification rates in soil due to amoxicillin-spiked pig manure. J Plant Nutr Soil Sc 174, 56-64. doi: 10.1002/jpln.200900210.

Kotzerke A, Sharma S, Schauss K, Heuer H, Thiele-Bruhn S, Smalla K, Wilke BM, Schloter M (2008) Alterations in soil microbial activity and N-transformation processes due to sulfadiazine loads in pigmanure. Environ Pollut 153, 315-322. doi: 10.1016/j.envpol.2007.08.020.

Kowalchuk G A, Stephen J R (2001) Ammonia-oxidizing bacteria: A model for molecular microbial ecology. Annu Rev Microbiol 55 485-529.

Kümmerer K (2009a) Antibiotics in the aquatic environment - A review - Part I. Chemosphere 75, 417-434. doi: 10.1016/j.chemosphere.2008.11.086.

Kümmerer K (2009b) The presence of pharmaceuticals in the environment due to human use - present knowledge and future challenges. J Environ Manage 90, 2354-2366. doi: 10.1016/j.jenvman.2009.01.023.

Larsson D G J (2014) Pollution from drug manufacturing: review and perspectives. Philos T Roy Soc B 369, 20130571. http://dx.doi.org/10.1098/rstb.2013.0571.

Liu B., Li Y, Zhang X, Wang J, Gao M (2014) Combined effects of chlortetracycline and dissolved organic matter extracted from pig manure on the functional diversity of soil microbial community. Soil Biol Biochem 74 148-155. doi: 10.1016/j.soilbio.2014.03.005.

Lotti T, Cordola M, Kleerebezem R, Caffaz S, Lubello C, van Loosdrecht MCM (2012) Inhibition effect of swine wastewater heavy metals and antibiotics on anammox activity. Water Sci Technol 66, 1519-1526. doi: $10.2166 /$ wst.2012.344.

Luczkiewicz A, Felis E, Ziembinska A, Gnida A, Kotlarska E, Olanczuk-Neyman K, Surmacz-Gorska J (2013) Resistance of Escherichia coli and Enterococcus spp. to selected antimicrobial agents present in municipal wastewater. J Water Health 11, 600-612. doi: 10.2166/wh.2013.130.

Nesme J, Cecillon S, Delmont TO, Monier JM, Vogel TM, Simonet P (2014) Large-scale metagenomic-based study of antibiotic resistance in the environment. Curr Biol 24, 1096-1100. doi: 10.1016/j.cub.2014.03.036.

Nordberg M, Templeton DM, Andersen O, Duffus JH (2009) Glossary of terms used in ecotoxicology (IUPAC Recommendations 2009). Pure Appl Chem 81, 829-970. doi: 10.1351/pac-rec-08-07-09.

Näslund J, Hedman JE, Agestrand C (2008) Effects of the antibiotic ciprofloxacin on the bacterial community structure and degradation of pyrene in marine sediment. Aquat Toxicol 90,223-227.

Philippot L, Hallin S (2005) Finding the missing link between diversity and activity using denitrifying bacteria as a model functional community. Curr Opin Microbiol 8 (3) 234-239.

Prosser JI (1989) Autotrophic nitrification in bacteria. Adv Microb Physiol 30, 125-181. 
Reichel R, Rosendahl I, Peeters ETHM, Focks E, Groeneweg J, Bierl R, Schlichting A, Amelung W, ThieleBruhn S (2013) Effects of slurry from sulfadiazine- (SDZ) and difloxacin- (DIF) medicated pigs on the structural diversity of microorganisms in bulk and rhizosphere soil. Soil Biol Biochem 62, 82-91. doi: 10.1016/j.soilbio.2013.03.007.

Rico A, Dimitrov MR, Van Wijngaarden RPA, Satapornvanit K, Smidt H, Van den Brink PJ (2014) Effects of the antibiotic enrofloxacin on the ecology of tropical eutrophic freshwater microcosms. Aquat Toxicol 147, 92-104. doi: 10.1016/j.aquatox.2013.12.008.

Roose-Amsaleg C, Yan C, Hoang AM, Laverman AM (2013) Chronic exposure of river sediments to environmentally relevant levels of tetracycline affects bacterial communities but not denitrification rates. Ecotoxicology 22, 1467-1478. doi: 10.1007/s10646-013-1133-2.

Rosendahl I, Siemens J, Kindler R, Groeneweg J, Zimmermann J, Czerwinski S, Lamshoeft M, Laabs V, Wilke BM, Vereecken H, Amelung W (2012) Persistence of the fluoroquinolone antibiotic difloxacin in soil and lacking effects on nitrogen turnover. J Environ Qual 41,1275-1283. doi: 10.2134/jeq2011.0459.

Schauss K, Focks A, Heuer H, Kotzerke A, Schmitt H, Thiele-Bruhn S, Smalla K. Wilke B M, Matthies M, Amelung W, Klasmeier J, Schloter M (2009) Analysis, fate and effects of the antibiotic sulfadiazine in soil ecosystems. Trend Anal Chem 28, 612-618.

Schmidt S, Winter J, Gallert C (2012) Long-term effects of antibiotics on the elimination of chemical oxygen demand, nitrification, and viable bacteria in laboratory-scale wastewater treatment plants. Arch Environ Con Tox 63, 354-364. doi: 10.1007/s00244-012-9773-4.

Schmieder R, Edwards R (2012) Insights into antibiotic resistance through metagenomic approaches. Future Microbiol 7, 73-89. doi: 10.2217/fmb.11.135.

Servais P, Passerat J. (2009) Antimicrobial resistance of fecal bacteria in waters of the Seine river watershed (France). Sci Total Environ 408, 365-372. doi: 10.1016/j.scitotenv.2009.09.042.

Shen T, Stieglmeier M, Dai J, Urich T, Schleper C (2013) Responses of the terrestrial ammonia-oxidizing archaeon Ca. Nitrososphaera viennensis and the ammonia-oxidizing bacterium Nitrosospira multiformis to nitrification inhibitors. FEMS Microbiol Lett 344, 121-129. doi: 10.1111/1574-6968.12164.

Spieck E, Lipski A (2011) Cultivation, growth physiology, and chemotaxonomy of nitrite-oxidizing bacteria. In Martin G. Klotz, editor: Methods in Enzymology, Vol. 486, Burlington: Academic Press, 2011, pp. 109-130. ISBN: 978-0-12-381294-0 Elsevier Inc. Academic Press.

Stewart PS (2002) Mechanisms of antibiotic resistance in bacterial biofilms. Int J Med Microbiol 292, 107-113. doi: 10.1078/1438-4221-00196.

Strous M, Kuenen JG, Jetten MSM (1999) Key physiology of anaerobic ammonium oxidation. Appl Environ Microbiol 65, 3248-3250.

Thiele-Bruhn S (2003) Pharmaceutical antibiotic compounds in soils - a review. J Plant Nutr Soil Sc 166, 145167. doi: 10.1002/jpln.200390023.

Thiele-Bruhn S, Beck IC (2005) Effects of sulfonamide and tetracycline antibiotics on soil microbial activity and microbial biomass. Chemosphere 59, 457-465. doi: 10.1016/j.chemosphere.2005.01.023.

Toth JD, Feng Y, Dou Z (2011) Veterinary antibiotics at environmentally relevant concentrations inhibit soil iron reduction and nitrification. Soil Biol Biochem 43, 2470-2472. doi: 10.1016/j.soilbio.2011.09.004. 
Tourna M, Stieglmeier M, Spang A, Konneke M, Schintlmeister A, Urich T, Engel M, Schloter M, Wagner M, Richter A, Schleper C (2011) Nitrososphaera viennensis, an ammonia oxidizing archaeon from soil. P Natl Acad Sci USA 108, 8420-8425. doi: 10.1073/pnas.1013488108.

Treusch A H, Leininger S, Kletzin A, Schuster S C, Klenk H P, Schleper C (2005) Novel genes for nitrite reductase and Amo-related proteins indicate a role of uncultivated mesophilic crenarchaeota in nitrogen cycling. Environ Microbiol 7 (12) 1985-1995.

Underwood JC, Harvey RW, Metge DW, Repert DA, Baumgartner LK, Smith RL, Roane TM, Barber LB (2011) Effects of the antimicrobial sulfamethoxazole on groundwater bacterial enrichment. Environ Sci Technol 45, 3096-3101. doi: 10.1021/es103605e.

Wunder DB Tan DT, LaPara TM, Hozalski RM (2013) The effects of antibiotic cocktails at environmentally relevant concentrations on the community composition and acetate biodegradation kinetics of bacterial biofilms. Chemosphere 90, 2261-2266. doi: 10.1016/j.chemosphere.2012.10.031.

Yamamura S, Watanabe K, Suda W, Tsuboi S, Watanabe M (2014) Effect of antibiotics on redox transformations of arsenic and diversity of arsenite-oxidizing bacteria in sediment microbial mommunities. Environ Sci Technol 48, 350-357. doi: 10.1021/es403971s.

Yan C, Dinh QT, Chevreuil M, Garnier J, Roose-Amsaleg C, Labadie P, Laverman AM (2013) The effect of environmental and therapeutic concentrations of antibiotics on nitrate reduction rates in river sediment. Water Res 47, 3654-3662. doi: http://dx.doi.org/10.1016/j.watres.2013.04.025.

Yergeau E, Sanschagrin S, Waiser MJ, Lawrence JR, Greer CW (2012) Sub-inhibitory concentrations of different pharmaceutical products affect the meta-transcriptome of river biofilm communities cultivated in rotating annular reactors. Environ Microbiol Rep 4 (3) 350-359. doi: 10.1111/j.17582229.2012.00341.x.

Zumft WG (1997) Cell biology and molecular basis of denitrification. Microbiol Mol Biol R 61, 533-616. 
574 Table 1. List of observed effects of antibiotic on biogeochemical processes in environmental samples; A and C, 575 mean acute and chronic effect, respectively; An exposure was designed as chronic if the duration of the exposure 576 reached a value higher than the life-span of the targeted organisms and eventually if the level of exposure was 577 low (ng- $\mu \mathrm{g} / \mathrm{L}$ or $\mathrm{kg}$ ). WWTP designs waste water treatment plant and $\mathrm{S}$ and $\mathrm{C}$ design single and continuous 578 addition, respectively. Processes from the nitrogen cycle are in bold. ${ }^{1}$ Calculated by the authors. ${ }^{2}$ Depending on 579 soil type tested. 


\begin{tabular}{|c|c|c|c|c|c|c|c|c|c|c|}
\hline \multirow{2}{*}{$\begin{array}{l}\text { Microbial } \\
\text { Process }\end{array}$} & \multirow{2}{*}{$\begin{array}{l}\text { Chronic } \\
\text { /Acute }\end{array}$} & \multicolumn{5}{|l|}{ Antibiotic } & \multicolumn{2}{|l|}{ Effects } & \multirow[t]{2}{*}{ Environment } & \multirow[t]{2}{*}{ Reference } \\
\hline & & Molecule & $\begin{array}{l}\text { Nominal } \\
\text { concentration }\end{array}$ & Addition & Duration & $\begin{array}{l}\text { Quantification } \\
\text { (loss) }\end{array}$ & $\begin{array}{l}\text { (approximate } \\
\% \\
\text { changement) }\end{array}$ & $\begin{array}{l}\text { Effective } \\
\text { concentration }\end{array}$ & & \\
\hline $\begin{array}{l}\text { Acetate } \\
\text { biodegradation }\end{array}$ & $\mathbf{C}$ & $\begin{array}{l}\text { sulfamethoxazole, } \\
\text { erythromycin, and } \\
\text { ciprofloxacin (mixture) }\end{array}$ & $\begin{array}{l}0.33-3.33 \\
\mu \mathrm{g} / \mathrm{L}\end{array}$ & $\mathrm{C}$ & weeks & no & no effect & - & water/biofilm & $\begin{array}{l}\text { Wunder et al. } \\
2013\end{array}$ \\
\hline Anammox & $\mathbf{A}$ & $\begin{array}{l}\text { tetracycline } \\
\text { hydrochloride }\end{array}$ & $\begin{array}{l}100-1,000 \\
\mathrm{mg} / \mathrm{L}\end{array}$ & $S$ & hours & no & $\begin{array}{l}\text { inhibition } \\
(30 \%)\end{array}$ & $100 \mathrm{mg} / \mathrm{L}$ & WWTP & $\begin{array}{l}\text { Fernandez et } \\
\text { al. } 2009\end{array}$ \\
\hline Anammox & $\mathbf{C}$ & $\begin{array}{l}\text { tetracycline } \\
\text { hydrochloride }\end{array}$ & $50 \mathrm{mg} / \mathrm{L}$ & $\mathrm{C}$ & months & no & $\begin{array}{l}\text { reversible } \\
\text { inhibition } \\
(40 \%)\end{array}$ & $50 \mathrm{mg} / \mathrm{L}$ & WWTP & $\begin{array}{l}\text { Fernandez et } \\
\text { al. } 2009\end{array}$ \\
\hline Anammox & $\mathbf{A}$ & sulfathiazole & $\begin{array}{l}100-1,000 \\
\mathrm{mg} / \mathrm{L}\end{array}$ & S & hours & no & $\begin{array}{l}\text { inhibition (up } \\
\text { to } 50 \% \text { ) } \\
\text { decrease with } \\
\text { the duration of } \\
\text { exposure }\end{array}$ & $450 \mathrm{mg} / \mathrm{L}$ & WWTP & $\begin{array}{l}\text { Lotti et al. } \\
2012\end{array}$ \\
\hline Anammox & $\mathbf{C}$ & sulfathiazole & $\begin{array}{l}100 \text { and } 500 \\
\mathrm{mg} / \mathrm{L}\end{array}$ & $S$ & weeks & no & $\begin{array}{l}\text { inhibition (final } \\
\text { decrease of } \\
50 \% \text { ) }\end{array}$ & $100 \mathrm{mg} / \mathrm{L}$ & WWTP & $\begin{array}{l}\text { Lotti et al. } \\
2012\end{array}$ \\
\hline Anammox & $\mathbf{A}$ & oxytetracycline & $\begin{array}{l}100-1,000 \\
\mathrm{mg} / \mathrm{L}\end{array}$ & $S$ & hours & no & $\begin{array}{l}\text { inhibition (up } \\
\text { to } 20 \% \text { ) } \\
\text { decrease with } \\
\text { the duration of } \\
\text { exposure }\end{array}$ & $200 \mathrm{mg} / \mathrm{L}$ & WWTP & $\begin{array}{l}\text { Lotti et al. } \\
2012\end{array}$ \\
\hline Anammox & $\mathbf{C}$ & oxytetracycline & $\begin{array}{l}100 \text { and } 500 \\
\mathrm{mg} / \mathrm{L}\end{array}$ & $S$ & weeks & no & $\begin{array}{l}\text { inhibition (final } \\
\text { decrease of } \\
25 \% \text { ) }\end{array}$ & $100 \mathrm{mg} / \mathrm{L}$ & WWTP & $\begin{array}{l}\text { Lotti et al. } \\
2012\end{array}$ \\
\hline Anammox & $\mathbf{A}$ & chloramphenicol & $\begin{array}{l}250-1,000 \\
\mathrm{mg} / \mathrm{L}\end{array}$ & $\mathrm{S}$ & hours & no & $\begin{array}{l}\text { inhibition } \\
(40 \%)\end{array}$ & $250 \mathrm{mg} / \mathrm{L}$ & WWTP & $\begin{array}{l}\text { Fernandez et } \\
\text { al. } 2009\end{array}$ \\
\hline Anammox & C & chloramphenicol & $20 \mathrm{mg} / \mathrm{L}$ & $\mathrm{C}$ & months & no & $\begin{array}{l}\text { irreversible } \\
\text { inhibition (up } \\
\text { to } 80 \% \text { ) }\end{array}$ & $20 \mathrm{mg} / \mathrm{L}$ & WWTP & $\begin{array}{l}\text { Fernandez et } \\
\text { al. } 2009\end{array}$ \\
\hline $\begin{array}{l}\text { Arsenate } \\
\text { reduction }\end{array}$ & $\mathbf{C}$ & tetracycline & $50 \mathrm{mg} / \mathrm{L}$ & $\mathrm{S}$ & days & no & accelerated & $50 \mathrm{mg} / \mathrm{L}$ & sediment & $\begin{array}{l}\text { Yamamura et } \\
\text { al. } 2014\end{array}$ \\
\hline $\begin{array}{l}\text { Arsenate } \\
\text { reduction }\end{array}$ & $\mathbf{C}$ & lincomycin & $50 \mathrm{mg} / \mathrm{L}$ & $\mathrm{S}$ & days & no & minor effect & $50 \mathrm{mg} / \mathrm{L}$ & sediment & $\begin{array}{l}\text { Yamamura et } \\
\text { al. } 2014\end{array}$ \\
\hline $\begin{array}{l}\text { Arsenate } \\
\text { reduction }\end{array}$ & $\mathbf{C}$ & erythromycin & $50 \mathrm{mg} / \mathrm{L}$ & $S$ & days & no & minor effect & $50 \mathrm{mg} / \mathrm{L}$ & sediment & $\begin{array}{l}\text { Yamamura et } \\
\text { al. } 2014\end{array}$ \\
\hline
\end{tabular}




\begin{tabular}{|c|c|c|c|c|c|c|c|c|c|c|}
\hline $\begin{array}{l}\text { Arsenate } \\
\text { reduction }\end{array}$ & C & chloramphenicol & $50 \mathrm{mg} / \mathrm{L}$ & $\mathrm{S}$ & days & no & $\begin{array}{l}\text { no effect } \\
\text { (aerobic), } \\
\text { inhibition } \\
\text { (anaerobic) }\end{array}$ & $50 \mathrm{mg} / \mathrm{L}$ & sediment & $\begin{array}{l}\text { Yamamura et } \\
\text { al. } 2014\end{array}$ \\
\hline $\begin{array}{l}\text { Arsenate } \\
\text { reduction }\end{array}$ & C & ampicilline & $50 \mathrm{mg} / \mathrm{L}$ & $S$ & days & no & $\begin{array}{l}\text { partial } \\
\text { inhibition }\end{array}$ & $50 \mathrm{mg} / \mathrm{L}$ & sediment & $\begin{array}{l}\text { Yamamura et } \\
\text { al. } 2014\end{array}$ \\
\hline $\begin{array}{l}\text { Arsenite } \\
\text { oxidation }\end{array}$ & C & tetracycline & $50 \mathrm{mg} / \mathrm{L}$ & S & days & no & delayed & $50 \mathrm{mg} / \mathrm{L}$ & sediment & $\begin{array}{l}\text { Yamamura et } \\
\text { al. } 2014\end{array}$ \\
\hline $\begin{array}{l}\text { Arsenite } \\
\text { oxidation }\end{array}$ & C & lincomycin & $50 \mathrm{mg} / \mathrm{L}$ & S & days & no & minor effect & $50 \mathrm{mg} / \mathrm{L}$ & sediment & $\begin{array}{l}\text { Yamamura et } \\
\text { al. } 2014\end{array}$ \\
\hline $\begin{array}{l}\text { Arsenite } \\
\text { oxidation }\end{array}$ & C & erythromycin & $50 \mathrm{mg} / \mathrm{L}$ & $S$ & days & no & minor effect & $50 \mathrm{mg} / \mathrm{L}$ & sediment & $\begin{array}{l}\text { Yamamura et } \\
\text { al. } 2014\end{array}$ \\
\hline $\begin{array}{l}\text { Arsenite } \\
\text { oxidation }\end{array}$ & C & chloramphenicol & $50 \mathrm{mg} / \mathrm{L}$ & $\mathrm{S}$ & days & no & inhibition & $50 \mathrm{mg} / \mathrm{L}$ & sediment & $\begin{array}{l}\text { Yamamura et } \\
\text { al. } 2014\end{array}$ \\
\hline $\begin{array}{l}\text { Arsenite } \\
\text { oxidation }\end{array}$ & C & ampicilline & $50 \mathrm{mg} / \mathrm{L}$ & S & days & no & indeterminable & $50 \mathrm{mg} / \mathrm{L}$ & sediment & $\begin{array}{l}\text { Yamamura et } \\
\text { al. } 2014\end{array}$ \\
\hline $\begin{array}{l}\text { Chemical } \\
\text { oxygen } \\
\text { demand } \\
\text { removal }\end{array}$ & C & $\begin{array}{l}\text { ciprofloxacin, } \\
\text { gentamicin, } \\
\text { sulfamethoxazole, } \\
\text { trimetoprim, } \\
\text { vancomycin (mixture) }\end{array}$ & $0.1-40 \mathrm{mg} / \mathrm{L}$ & $\mathrm{C}$ & months & extrapolation & $\begin{array}{l}\text { reversible } \\
\text { inhibition } \\
(25 \%)\end{array}$ & $30 \mathrm{mg} / \mathrm{L}$ & WWTP & $\begin{array}{l}\text { Schmidt et al. } \\
2012\end{array}$ \\
\hline Denitrification & $\mathbf{C}$ & ciprofloxacin & $10-50 \mathrm{mg} / \mathrm{L}$ & $\mathrm{S}$ & weeks & $\begin{array}{l}\text { yes, } \\
\text { biotransformati } \\
\text { on }\end{array}$ & $\begin{array}{l}\text { inhibition } \\
(25 \%)\end{array}$ & $50 \mathrm{mg} / \mathrm{L}$ & $\begin{array}{l}\text { enrichment } \\
\text { cultures }\end{array}$ & $\begin{array}{l}\text { Liu et al. } \\
2014\end{array}$ \\
\hline Denitrification & C & sulfamethoxazole & $\begin{array}{l}1.2 \mu \mathrm{g} / \mathrm{L}-0.5 \\
\mathrm{~g} / \mathrm{L}\end{array}$ & $\mathrm{S}$ & weeks & no & $\begin{array}{l}\text { inhibition } \\
(47 \%)\end{array}$ & $1.2 \mu \mathrm{g} / \mathrm{L}$ & groundwater & $\begin{array}{l}\text { Underwood } \\
\text { et al. } 2011\end{array}$ \\
\hline Denitrification & C & sulfamethazine & $0.01-1 \mathrm{mg} / \mathrm{L}$ & $\mathrm{S}$ & days & yes & $\begin{array}{l}\text { inhibition of } \\
\text { nitrate removal } \\
(17 \%) \text { and } \\
\text { nitrite } \\
\text { production } \\
(82 \%)^{1}\end{array}$ & $\underset{\mathrm{mg} / \mathrm{L}}{0.01 \mathrm{mg} / \mathrm{L} \_1}$ & groundwater & $\begin{array}{l}\text { Ahmad et al. } \\
2014\end{array}$ \\
\hline Denitrification & C & chlortetracycline & $0.01-1 \mathrm{mg} / \mathrm{L}$ & $\mathrm{S}$ & days & $\begin{array}{l}\text { yes, no } \\
\text { degradation }\end{array}$ & $\begin{array}{l}\text { inhibition of } \\
\text { nitrate removal } \\
(15.4 \%) \_ \text {and } \\
\text { nitrite } \\
\text { production } \\
(31 \%)^{1}\end{array}$ & $1 \mathrm{mg} / \mathrm{L} \_1 \mathrm{mg} / \mathrm{L}$ & groundwater & $\begin{array}{l}\text { Ahmad et al. } \\
2014\end{array}$ \\
\hline Denitrification & C & flumequine & $\begin{array}{l}0.1 \mu \mathrm{g} / \mathrm{L}-50 \\
\mathrm{mg} / \mathrm{L}\end{array}$ & $\mathrm{C}$ & weeks & yes $(62 \%)$ & $\begin{array}{l}\text { inhibition (41 } \\
\%)\end{array}$ & $50 \mathrm{mg} / \mathrm{L}$ & sediment & $\begin{array}{l}\text { Yan et al. } \\
2013\end{array}$ \\
\hline
\end{tabular}




\begin{tabular}{|c|c|c|c|c|c|c|c|c|c|c|}
\hline Denitrification & $\mathbf{C}$ & sulfamethoxazole & $\begin{array}{l}0.2 \mu \mathrm{g} / \mathrm{L}-50 \\
\mathrm{mg} / \mathrm{L}\end{array}$ & $\mathrm{C}$ & weeks & yes $(93 \%)$ & $\begin{array}{l}\text { inhibition } \\
(39 \%)\end{array}$ & $50 \mathrm{mg} / \mathrm{L}$ & sediment & $\begin{array}{l}\text { Yan et al. } \\
2013\end{array}$ \\
\hline Denitrification & $\mathbf{C}$ & vancomycine & $\begin{array}{l}0.3 \mu \mathrm{g} / \mathrm{L}-0.2 \\
\mathrm{mg} / \mathrm{L}\end{array}$ & $\mathrm{C}$ & weeks & no & no effect & - & sediment & $\begin{array}{l}\text { Yan et al. } \\
2013\end{array}$ \\
\hline Denitrification & C & tetracycline & $\begin{array}{l}0.9 \mu \mathrm{g} / \mathrm{L}-7 \\
\mathrm{mg} / \mathrm{L}\end{array}$ & $\mathrm{C}$ & weeks & yes $(92 \%)$ & no effect & - & sediment & $\begin{array}{l}\text { Roose- } \\
\text { Amsaleg et } \\
\text { al. } 2013\end{array}$ \\
\hline Denitrification & $\mathbf{A}$ & sulfamethazine & $0.05-100 \mu \mathrm{g} / \mathrm{L}$ & S & hours & yes & $\begin{array}{l}\text { inhibition (20- } \\
30 \%)\end{array}$ & $50 \mathrm{ng} / \mathrm{L}$ & sediment & $\begin{array}{l}\text { Hou et al. } \\
2015\end{array}$ \\
\hline Denitrification & $\mathbf{A}$ & erythromycin & $1 \mathrm{mg} / \mathrm{L}$ & $\mathrm{S}$ & hours & no & $\begin{array}{l}\text { inhibition } \\
\text { (around 37\%) }\end{array}$ & $1 \mathrm{mg} / \mathrm{L}$ & sediment & $\begin{array}{l}\text { Costanzo et } \\
\text { al. } 2005\end{array}$ \\
\hline Denitrification & A & clarithromycin & $1 \mathrm{mg} / \mathrm{L}$ & $\mathrm{S}$ & hours & no & $\begin{array}{l}\text { inhibition } \\
\text { (around 37\%) }\end{array}$ & $1 \mathrm{mg} / \mathrm{L}$ & sediment & $\begin{array}{l}\text { Costanzo et } \\
\text { al. } 2005\end{array}$ \\
\hline Denitrification & $\mathbf{A}$ & ciprofloxacin & $\begin{array}{l}0.1-1,000 \\
\mu \mathrm{g} / \mathrm{L}\end{array}$ & $\mathrm{S}$ & hours & no & no effect & - & sediment & $\begin{array}{l}\text { Costanzo et } \\
\text { al. } 2005\end{array}$ \\
\hline Denitrification & A & $\begin{array}{l}\text { amoxicillin, clavulanic } \\
\text { acid }\end{array}$ & $1 \mathrm{mg} / \mathrm{L}$ & $\mathrm{S}$ & hours & no & no effect & - & sediment & $\begin{array}{l}\text { Costanzo et } \\
\text { al. } 2005\end{array}$ \\
\hline Denitrification & $\mathbf{A}$ & amoxicillin & $1 \mathrm{mg} / \mathrm{L}$ & S & hours & no & $\begin{array}{l}\text { inhibition } \\
\text { (around 37\%) }\end{array}$ & $1 \mathrm{mg} / \mathrm{L}$ & sediment & $\begin{array}{l}\text { Costanzo et } \\
\text { al. } 2005\end{array}$ \\
\hline Denitrification & C & tetracycline & $1-1,000 \mu \mathrm{g} / \mathrm{kg}$ & $\mathrm{S}$ & days & no & no effect & - & soil & $\begin{array}{l}\text { Conkle and } \\
\text { White, } 2012\end{array}$ \\
\hline Denitrification & C & sulfamethoxazole & $1-1,000 \mu \mathrm{g} / \mathrm{kg}$ & $\mathrm{S}$ & days & no & inhibition & $500 \mu \mathrm{g} / \mathrm{kg}$ & soil & $\begin{array}{l}\text { Conkle and } \\
\text { White, } 2012\end{array}$ \\
\hline Denitrification & C & ciprofloxacin & $1-1,000 \mu \mathrm{g} / \mathrm{kg}$ & $\mathrm{S}$ & days & no & no effect & - & soil & $\begin{array}{l}\text { Conkle and } \\
\text { White, } 2012\end{array}$ \\
\hline Denitrification & C & sulfadiazine & $\begin{array}{l}10 \text { and } 100 \\
\mathrm{mg} / \mathrm{kg}\end{array}$ & $\mathrm{S}$ & weeks & yes $(66-100 \%)$ & $\begin{array}{l}\text { inhibition } \\
\text { (around 70\%) }\end{array}$ & $10 \mathrm{mg} / \mathrm{kg}$ & soil & $\begin{array}{l}\text { Kotzerke et } \\
\text { al. } 2008\end{array}$ \\
\hline Denitrification & C & difloxacin, sarafloxacin & $7-12 \mu \mathrm{g} / \mathrm{kg}$ & $\mathrm{S}$ & month & yes & no effect & - & soil & $\begin{array}{l}\text { Rosendahl et } \\
\text { al. } 2012\end{array}$ \\
\hline Denitrification & C & difloxacin & $1-100 \mathrm{mg} / \mathrm{kg}$ & $\mathrm{S}$ & weeks & yes & $\begin{array}{l}\text { inhibition } \\
(50 \%)\end{array}$ & $10 \mathrm{mg} / \mathrm{kg}$ & soil & $\begin{array}{l}\text { Kotzerke et } \\
\text { al. } 2011\end{array}$ \\
\hline Denitrification & A & chloramphenicol & $\begin{array}{l}100-2,000 \\
\mathrm{mg} / \mathrm{L}\end{array}$ & $\mathrm{S}$ & hours & no & $\begin{array}{l}\text { inhibition (19- } \\
41 \%)^{2}\end{array}$ & $100 \mathrm{mg} / \mathrm{L}$ & soil & $\begin{array}{l}\text { Murray and } \\
\text { Knowles, } \\
1999\end{array}$ \\
\hline Iron reduction & C & $\begin{array}{l}\text { sulfapyridine or } \\
\text { oxytetracycline }\end{array}$ & $\begin{array}{l}0.02-500 \\
\mathrm{mg} / \mathrm{kg}\end{array}$ & $\mathrm{S}$ & days & yes & $\begin{array}{l}\text { inhibition } \\
(10 \%)^{1}\end{array}$ & $\begin{array}{c}\text { ED 10 } \\
0.003 \_7.35 \\
\mu \mathrm{g} / \mathrm{g}\end{array}$ & soil & $\begin{array}{l}\text { Thiele-Bruhn } \\
\text { and Beck, } \\
2005\end{array}$ \\
\hline Iron reduction & C & sulfadimethoxin & $25-200 \mu \mathrm{g} / \mathrm{kg}$ & $\mathrm{S}$ & weeks & no & $\begin{array}{l}\text { inhibition } \\
(>95 \%)\end{array}$ & $25 \mu \mathrm{g} / \mathrm{kg}$ & soil & $\begin{array}{l}\text { Toth et al. } \\
2011\end{array}$ \\
\hline Iron reduction & C & monensin & $10-100 \mu \mathrm{g} / \mathrm{kg}$ & $\mathrm{S}$ & weeks & no & reversible & $10-100 \mu \mathrm{g} / \mathrm{kg}$ & soil & Toth et al. \\
\hline
\end{tabular}




\begin{tabular}{|c|c|c|c|c|c|c|c|c|c|c|}
\hline $\begin{array}{l}\text { Methanogenesi } \\
\mathrm{s}\end{array}$ & C & ciprofloxacin & $10-100 \mathrm{mg} / \mathrm{L}$ & S & weeks & $\begin{array}{l}\text { yes, no } \\
\text { biotransformati } \\
\text { on }\end{array}$ & $\begin{array}{l}\text { inhibition } \\
\text { inhibition } \\
(40 \%)\end{array}$ & $80 \mathrm{mg} / \mathrm{L}$ & $\begin{array}{l}\text { enrichment } \\
\text { cultures }\end{array}$ & $\begin{array}{l}2011 \\
\text { Liu et al. } \\
2014\end{array}$ \\
\hline $\begin{array}{l}\text { Methanogenesi } \\
\mathrm{s}\end{array}$ & $\mathbf{A}$ & sulfamethoxazole & $10-400 \mathrm{mg} / \mathrm{L}$ & S & days & no & inhibition & $\begin{array}{c}\mathrm{IC} 50>400 \\
\mathrm{mg} / \mathrm{L}\end{array}$ & $\begin{array}{l}\text { enrichment } \\
\text { cultures }\end{array}$ & $\begin{array}{l}\text { Fountoulakis } \\
\text { et al. } 2004\end{array}$ \\
\hline $\begin{array}{l}\text { Methanogenesi } \\
\mathrm{s}\end{array}$ & $\mathbf{A}$ & ofloxacine & $10-400 \mathrm{mg} / \mathrm{L}$ & S & days & no & inhibition & $\begin{array}{c}\mathrm{IC} 50=334 \\
\mathrm{mg} / \mathrm{L}\end{array}$ & $\begin{array}{l}\text { enrichment } \\
\text { cultures }\end{array}$ & $\begin{array}{l}\text { Fountoulakis } \\
\text { et al. } 2004\end{array}$ \\
\hline $\begin{array}{l}\text { Methanogenesi } \\
\mathrm{s}\end{array}$ & $\mathbf{C}$ & sulfamethoxazole & $1-1,000 \mu \mathrm{g} / \mathrm{kg}$ & S & days & no & $\begin{array}{l}\text { stimulation } \\
(30 \%)\end{array}$ & $500 \mu \mathrm{g} / \mathrm{kg}$ & soil & $\begin{array}{l}\text { Conkle and } \\
\text { White, } 2012\end{array}$ \\
\hline $\begin{array}{l}\text { Methanogenesi } \\
\mathrm{s}\end{array}$ & $\mathbf{C}$ & tetracycline & $1-1,000 \mu \mathrm{g} / \mathrm{kg}$ & $S$ & days & no & no effect & - & soil & $\begin{array}{l}\text { Conkle and } \\
\text { White, } 2012\end{array}$ \\
\hline $\begin{array}{l}\text { Methanogenesi } \\
\mathrm{s}\end{array}$ & $\mathbf{C}$ & ciprofloxacin & $1-1,000 \mu \mathrm{g} / \mathrm{kg}$ & $S$ & days & no & $\begin{array}{l}\text { inhibition } \\
(25 \%)\end{array}$ & $1 \mu \mathrm{g} / \mathrm{kg}$ & soil & $\begin{array}{l}\text { Conkle and } \\
\text { White, } 2012\end{array}$ \\
\hline Nitrification & $\mathbf{A}$ & colistin & $0.3-300 \mathrm{mg} / \mathrm{L}$ & $\mathrm{S}$ & hours & no & $\begin{array}{l}\text { no effect on } \\
\text { nitrite } \\
\text { oxidation }\end{array}$ & - & mixed culture & $\begin{array}{l}\text { Bressan et al. } \\
2013\end{array}$ \\
\hline Nitrification & $\mathbf{A}$ & colistin & $0.3-300 \mathrm{mg} / \mathrm{L}$ & $S$ & hours & no & $\begin{array}{l}\text { inhibition of } \\
\text { ammonia- } \\
\text { oxidation } \\
\text { (correlation) }\end{array}$ & $0.3-300 \mathrm{mg} / \mathrm{L}$ & mixed culture & $\begin{array}{l}\text { Bressan et al. } \\
2013\end{array}$ \\
\hline Nitrification & $\mathbf{C}$ & chloramphenicol & $10-250 \mathrm{mg} / \mathrm{L}$ & $\mathrm{C}$ & weeks & yes & no effect & - & mixed culture & $\begin{array}{l}\text { Campos et al. } \\
2001\end{array}$ \\
\hline Nitrification & $\mathbf{C}$ & $\begin{array}{l}\text { oxytetracycline } \\
\text { hydrochloride }\end{array}$ & $10-250 \mathrm{mg} / \mathrm{L}$ & $\mathrm{C}$ & weeks & yes & $\begin{array}{l}\text { inhibition } \\
(50 \%)\end{array}$ & $250 \mathrm{mg} / \mathrm{L}$ & mixed culture & $\begin{array}{l}\text { Campos et al. } \\
2001\end{array}$ \\
\hline Nitrification & $\mathbf{A}$ & $\begin{array}{l}\text { ofloxacin or } \\
\text { sulfamethoxazole }\end{array}$ & $2-10 \mathrm{mg} / \mathrm{L}$ & $S$ & hours & no & $\begin{array}{l}\text { inhibition ( } 75 \\
\text { and 60\%) }\end{array}$ & $\begin{array}{c}6 \mathrm{mg} / \mathrm{L} \text { for } \\
\text { each }\end{array}$ & pure culture & $\begin{array}{l}\text { Dokianakis et } \\
\text { al. } 2004\end{array}$ \\
\hline Nitrification & $\mathbf{C}$ & sulfadiazine & $\begin{array}{l}10 \text { and } 100 \\
\mathrm{mg} / \mathrm{kg}\end{array}$ & $\mathrm{S}$ & weeks & yes $(66-100 \%)$ & $\begin{array}{l}\text { inhibition } \\
\text { (around 25\%) }\end{array}$ & $100 \mathrm{mg} / \mathrm{kg}$ & soil & $\begin{array}{l}\text { Kotzerke et } \\
\text { al. } 2008\end{array}$ \\
\hline Nitrification & C & oxytetracycline & $12.5-75 \mathrm{mg} / \mathrm{L}$ & S & week & no & $\begin{array}{l}\text { inhibition } \\
(50 \%)^{1}\end{array}$ & $\begin{array}{c}\text { EC } 50=8.60- \\
26.96 \mathrm{mg} / \mathrm{L}\end{array}$ & water & $\begin{array}{l}\text { Klaver and } \\
\text { Matthews, } \\
1994\end{array}$ \\
\hline Nitrification & A & erythromycin & $1-267 \mathrm{mg} / \mathrm{L}$ & $\mathrm{S}$ & days & no & $\begin{array}{l}\text { inhibition } \\
(72 \%)\end{array}$ & $>20 \mathrm{mg} / \mathrm{L}$ & WWTP & $\begin{array}{l}\text { Alighardashi } \\
\text { et al. } 2009\end{array}$ \\
\hline Nitrification & C & $\begin{array}{l}\text { ciprofloxacin, } \\
\text { gentamicin, } \\
\text { sulfamethoxazole, } \\
\text { trimetoprim, } \\
\text { vancomycin (mixture) }\end{array}$ & $0.1-40 \mathrm{mg} / \mathrm{L}$ & $\mathrm{C}$ & months & extrapolation & $\begin{array}{l}\text { complete } \\
\text { inhibition }\end{array}$ & $40 \mathrm{mg} / \mathrm{L}$ & WWTP & $\begin{array}{l}\text { Schmidt et al. } \\
2012\end{array}$ \\
\hline Nitrification & A & tetracycline & 50 or 200 & S & hours & no & complete & $200 \mathrm{mg} / \mathrm{L}$ & WWTP & Katipoglu- \\
\hline
\end{tabular}


$\mathrm{mg} / \mathrm{L}$

\begin{tabular}{|c|c|c|c|c|c|c|c|}
\hline Nitrification & $\mathbf{A}$ & erythromycin & $\begin{array}{l}50 \text { or } 200 \\
\mathrm{mg} / \mathrm{L}\end{array}$ & $\mathrm{S}$ & hours & no & $\begin{array}{l}\text { complete } \\
\text { inhibition }\end{array}$ \\
\hline Nitrification & $\mathbf{C}$ & enrofloxacin & $1-1,000 \mu \mathrm{g} / \mathrm{L}$ & $\mathrm{C}$ & weeks & yes $(70-98 \%)$ & inhibition \\
\hline
\end{tabular}

\begin{tabular}{|c|c|c|c|c|}
\hline Nitrification & $\mathbf{C}$ & sulfadimethoxin & $25-200 \mu \mathrm{g} / \mathrm{kg}$ & S \\
\hline Nitrification & C & monensin & $10-100 \mu \mathrm{g} / \mathrm{kg}$ & S \\
\hline Nitrification & $\mathbf{C}$ & difloxacin, sarafloxacin & $7-12 \mu \mathrm{g} / \mathrm{kg}$ & S \\
\hline Nitrification & $\mathbf{C}$ & difloxacin & $1-100 \mathrm{mg} / \mathrm{kg}$ & $\mathrm{S}$ \\
\hline Nitrification & $\mathbf{C}$ & ciprofloxacin & $1-50 \mathrm{mg} / \mathrm{kg}$ & $\mathrm{S}$ \\
\hline $\begin{array}{l}\text { Organic carbon } \\
\text { removal }\end{array}$ & $\mathbf{A}$ & tetracycline & $\begin{array}{l}50 \text { or } 200 \\
\mathrm{mg} / \mathrm{L}\end{array}$ & S \\
\hline $\begin{array}{l}\text { Organic carbon } \\
\text { removal }\end{array}$ & $\mathbf{A}$ & erythromycin & $\begin{array}{l}50 \text { or } 200 \\
\mathrm{mg} / \mathrm{L}\end{array}$ & $S$ \\
\hline $\begin{array}{l}\text { PAH (Pyrene) } \\
\text { degradation }\end{array}$ & $\mathbf{C}$ & ciprofloxacin & $20-2,000 \mu \mathrm{g} / \mathrm{L}$ & $\mathrm{S}$ \\
\hline $\begin{array}{l}\text { Sulfate } \\
\text { reduction }\end{array}$ & $\mathbf{C}$ & $\begin{array}{l}\text { oxytetracycline, } \\
\text { oxolinic acid, } \\
\text { flumequine }\end{array}$ & $\begin{array}{l}400,100,100 \\
\mathrm{mg} / \mathrm{kg}\end{array}$ & S \\
\hline $\begin{array}{l}\text { Sulfate } \\
\text { reduction }\end{array}$ & $\mathbf{A}$ & $\begin{array}{l}\text { chloramphenicol + } \\
\text { streptomycine }\end{array}$ & $\begin{array}{l}20 \text { and } 100 \\
\mathrm{mg} / \mathrm{L}\end{array}$ & S \\
\hline
\end{tabular}

inhibition

$\begin{array}{ccl}50 \mathrm{mg} / \mathrm{L} & \text { WWTP } & \begin{array}{l}2013 \\ \text { Katipoglu- } \\ \end{array} \\ & & \text { Yazan et al. } \\ & 2013 \\ \text { NOEC } & \text { freshwater } & \text { Rico et al. } \\ \text { calculated by } & & 2014 \\ \text { authors: } & & \end{array}$

$\begin{array}{cc}\text { weeks } & \text { no } \\ \text { weeks } & \text { no } \\ \text { month } & \text { yes } \\ \text { weeks } & \text { yes } \\ \text { weeks } & \text { no } \\ \text { hours } & \text { no } \\ & \\ \text { hours } & \text { no }\end{array}$

inhibition

(60\%)

no effect

no effect

inhibition

(around 30\%)

stimulation

(20\%)

inhibition (25

and $71 \%$ )

inhibition (22
and 26\%)

month no

inhibition

(66\%)

months yes dissipation

reversible

ihibition $(90 \%)$

inhibition

$(90 \%)$ bacterial and

archaeal

ammonia

oxidizers to

enrofloxacin

10 and $1 \mu \mathrm{g} / \mathrm{L}$,

respectively)

$200 \mu \mathrm{g} / \mathrm{kg}$

soil

$$
\text { - }
$$

Yazan et al.

2013

2013

2014

Toth et al.

2011

Toth et al.

2011

Rosendahl et

al. 2012

Kotzerke et

al. 2011

Cui et al.

2014

Katipoglu-

Yazan et al.

2013

Katipoglu-

Yazan et al.

2013

Näslund et al.

2008

Hansen et al.

1992

400, 100, 100 sediment $\mathrm{mg} / \mathrm{kg}$

$20 \mathrm{mg} / \mathrm{L} \quad$ WWTP chloramphenic
Ingvorsen et al. 2003 
Sulfate

C

ciprofloxacin
10-80 mg/L $\quad \mathrm{S}$ $\mathrm{ol}+100 \mathrm{mg} / \mathrm{L}$

streptomycine

$10-80 \mathrm{mg} / \mathrm{L}$

yes, no reversible

biotransformati inhibition

on enrichment Liu et al.

cultures

2014 